\title{
Language Play and Linguistic Hybridity as Current Trends in Hungarian Word-Formation
}

\author{
Réka Benczes and Erzsébet Tóth-Czifra
}

\begin{abstract}
Hungarian literature on word-formation typically focuses on rule-governed descriptions of regular and typologically relevant patterns. However, there are plenty of other word-formation trends that usually go unnoticed in mainstream morphological research. The present paper will focus on two such trends: 1) rhyming and alliterating compounds such as pannon puma ['Pannonian puma,' a euphemism for Hungary's economic performance, playing upon the analogy of the 'Asian tiger']; and 2) creative prefixations such as meggugliz ['to google'] and felhájpol ['to hype']. Although these are seemingly two quite different patterns, they in fact share two significant traits. On the one hand, they are demonstrations of the fact that language users make full use of the creative possibilities in language and routinely play with sounds and meanings. On the other hand, they are also indications of the influential role of English in present-day Hungarian wordformation. It seems that language users are not only aware of the possibilities that this interference can result in, but are also able to exploit these consciously. This crossing of language boundaries is becoming increasingly inevitable with the global spread of English.
\end{abstract}

Keywords: Hungarian Derivational Morphology, Word-Formation, Linguistic Creativity, Neologism, Analogy, Compounding, Verbal Prefix

Biographies: Réka Benczes is Assistant Professor at the Department of American Studies, Eötvös Loránd University (ELTE), Budapest. She is the author of Creative Compounding in English (2006), Kognitiv nyelvészet ['Cognitive Linguistics'] (2010, with Zoltán Kövecses), and dozens of articles on lexical creativity and compounding. She has edited Metonymy in Cognitive Linguistics: Towards a Consensus View (2011, with Antonio Barcelona and Francisco José Ruiz de Mendoza Ibáñez) and Wrestling with Words and Meanings: Essays in Honour of Keith Allan (2014, with Kate Burridge). She was a Postdoctoral Research Fellow at Monash University (Melbourne) in 2012 and a Visiting Research Scholar at Indiana University, Bloomington, Indiana (USA) in 20132014. She also served as Visiting Professor at the Cognitive Science Program of Indiana University in 2015.

Erzsébet Tóth-Czifra is a PhD Candidate of the Cultural Linguistics Doctoral Research Program at ELTE, where she works under the supervision of Réka Benczes. She is also a guest lecturer at the Department for Hungarian as a Second Language, also at ELTE. She has been teaching Hungarian as a Second Language for five years. This teaching experience inspired her to study the complex relationship between culture, cognition, and language. Her research interests are: motivation in language, the meaningfulness and mental representation of grammar, linguistic creativity, and second language acquisition.

$(\mathrm{cc}) \mathrm{BY}$ ULIS D-Sente 
Benczes, Réka and Erzsébet Tóth-Czifra. "Language Play and Linguistic Hybridity as Current Trends in Hungarian Word-Formation." Hungarian Cultural Studies. e-Journal of the American Hungarian Educators Association, Volume 8 (2015): http://ahea.pitt.edu DOI: 10.5195/ahea.2015.212

\section{Introduction}

In 2014, the Hungarian Banking Association ran a competition open to the general public to find a Hungarian equivalent for "contactless payment" and "contactless debit/credit cards." The competition proved hugely popular, with more than 3,000 entries submitted. Eventually, the Association, together with a panel of linguists, chose érintés ['touching' as the best word for 'contactless payment' and érintökártya ['touching card'] for the card itself. The winning entries definitely reflect a rational choice on the part of the decision-makers, as both expressions evoke the semantic frame of contactless payment. Accordingly, in the case of érintés, the most salient part of the action (touching the card to a screen) stands (metonymically) for the action of paying, while érintökártya can be regarded as an instrument performing the role of the agent (after all, it is the card that is "doing" the payment). In contrasting the original English terms and their Hungarian translations, it is noteworthy that while the English expressions emphasize the fact that there is no physical contact whatsoever, the Hungarian ones focus on the fact that there is physical contact or touching - though not by a human agent but between the card and the reading device.

There were a vast number of entries in the contest that reflected a less serious and more playful attitude than the winning terms érintés/érintökártya. One such entry (which in fact was the runner-up for 'contactless debit/credit card') was the highly creative neologism, tacsikártya. The modifier, tacsi, is a play on the English verb touch (rendered in Hungarian spelling), but the (hypocoristic) $-i$ suffix lends the expression an informal, playful character, in line with the contemporary Hungarian trend to shorten words and add the $-i$ suffix to the shortened stem, as in bocsi (shortened form of bocsánat, 'sorry') and scores of other words, such as fagyi (shortened form of fagylalt, 'ice cream') or ubi sali (from uborka saláta, 'cucumber salad'). Tacsikártya is a manifestation of this trend (see Sólyom 2007 for further discussion and examples). At the same time, tacsi is (already) a meaningful word in Hungarian; it is a hypocoristic form of tacskó ('dachshund'). Tacsikártya highlights two features of present-day Hungarian: namely that 1) language users make full use of the creative possibilities in language and routinely play with the sounds and meanings; and 2) English has an influential role in Hungarian word-formation, and language users are not only aware of the possibilities of such interference but can also exploit these consciously. Interference of this kind has been routinely referred to as "linguistic hybridity" (see e.g. Földes 2014), the crossing of language boundaries, which is becoming increasingly inevitable. As Pennycook (2003: 515) emphasizes, such effects call for a reevaluation of (socio)linguistic research, where identities are not "pre-given and tied to nationalities." At the same time, linguistic interference or hybridity is often manifested in various forms of linguistic creativity and language play. As Amritavalli and Upendran (2011: 104) point out, jokes or other forms of language play that transgress more than one language are "extended puns along two languages" that can create a sense of community, since both the speaker and the hearer need to know both languages to some degree. In this way, such forms of language integrate two cultures, but at the same time also highlight the tension between them.

1 See http://www.bankkartya.hu/hirkategoria/hirek/cikk/erintokartya-lett-a-contactless-magyar-megfeleloje-eserintesnek-hivjuk-a-fizetest. 
Benczes, Réka and Erzsébet Tóth-Czifra. "Language Play and Linguistic Hybridity as Current Trends in Hungarian Word-Formation." Hungarian Cultural Studies. e-Journal of the American Hungarian Educators Association, Volume 8 (2015): http://ahea.pitt.edu DOI: 10.5195/ahea.2015.212

The present paper will focus on two word-formation patterns as representatives of linguistic creativity and interference par excellence. First, we will examine rhyming and alliterating compounds, such as pannon puma, which is a humorous expression for Hungary's economic performance, based upon the analogy of Asian tiger. Such compounds have routinely received very little attention in mainstream Hungarian linguistics and have typically been relegated to the poetic realm. Although rhyming and alliterating compounds are not perhaps as frequent in Hungarian as their counterparts in (American) English, they are nevertheless instantiations of language play and linguistic creativity. Second, we will analyze creative prefixations such as meggugliz ['to google'] and felhájpol ['to hype']. Here, we have a highly entrenched schema of Hungarian word-formation: [prefix...-(V)z(ik)/-V)l] is an inherent and productive feature of the language. (For a discussion see Ladányi 2007.) However, the morphemes that instantiate the schema are English loanwords. As such, this schema functions as an "internalizing/nativizing tool" (Thomason 2001: 145) for English borrowings.

The structure of the paper is the following: section one will discuss the role of language play and linguistic creativity in rhyming and alliterating compounds through the analysis of a couple of such Hungarian coinages. Section two will look at creative prefixations, more specifically meggugliz ['to google'], while the conclusion reviews the major findings of the article.

\section{Language Play in Rhyming and Alliterating Compounds}

Language play is a natural human ability. Right from the very beginning, when children start to acquire their native language, they have a "predilection for rhythm, rhyme, and alliteration" (Weir 1962: 103), and routinely play with the sounds they learn. In fact, the significance of rhythm in the process of language acquisition should not be underestimated: not only do newborns have a bias towards listening to speech as opposed to non-speech stimuli, but they are also sensitive to the intonational and stress patterns of their native language (Vouloumanos and Werker 2007, Friederici et al. 2007, Mehler et al. 1988). In fact, between the toddler and adolescent years children go through distinct stages of wordplay, which are directly related to proficiency in both language and literacy (Crystal 1996, Geller 1985). Later on, wordplay and more generally language play - which Crystal (1998:1) calls the "ludic" function of language - emerge on a number of levels. On the discourse level, for example, we like to repeat sounds in conversation (such as the repetition of the sound [t] in the utterance "It's not a good idea in terms of time"), which creates a musical effect (Tannen 2007: 84). Rhyme also abounds in aphorisms (as in "An apple a day keeps the doctor away"), where the rhyming quality - which eases the processing time of the statements — enhances people's perceptions of their truthfulness (McGlone and Tofighbakhsh 2000). Crystal (1998: 1) points out that-due to the prominence of the communicative aspect of language use (i.e. that we use language primarily to communicate information) - this area has been mostly ignored in linguistic inquiry, even though it should "be at the heart of any thinking we do about linguistic issues."

Perhaps one of the most conspicuous examples of language play is the innovative, witty, and often funny conceptualization that novel compounds such as street spam (advertisements posted on telephone poles, traffic lights, and other public areas) or snail mail (the physical delivery of mail, as by the postal service, considered as slow in comparison to electronic mail; a letter, etc., sent by post) exemplify. Such compounds are based on conceptual metaphors and metonymies and their humor lies in the unconventional application of these cognitive 
Benczes, Réka and Erzsébet Tóth-Czifra. "Language Play and Linguistic Hybridity as Current Trends in Hungarian Word-Formation." Hungarian Cultural Studies. e-Journal of the American Hungarian Educators Association, Volume 8 (2015): http://ahea.pitt.edu DOI: 10.5195/ahea.2015.212

mechanisms. Interestingly, they are also often motivated by alliteration (as in the case of street spam) or rhyme (as in the case of snail mail), which greatly enhance their ludic potential.

It has been noted by a number of linguists that English has a very strong tradition of rhyming and alliterating compounds, with rhyming compounds being the most frequent type of reduplicatives (Algeo 1998: 75, Hladký 1998, Benczes 2013, Rastall 2004). While rhyming and alliterating compounds do exist in Hungarian, as examples like bababörze (baba ['baby'] + börze ['fair']: “'baby clothes sale"), dilidoki (dili ['nuthouse'] + doki ['doc']: “shrink"), and nagyibugyi (nagyi ['grandma'] + bugyi ['panties']: "oversized panties") attest, they do not seem to be as common as is the case in English, especially in American English. An indication of the relative infrequency of rhyming and alliterating compounds in Hungarian can be found in Sólyom (2007), who collected and analyzed Hungarian neologisms that appeared around the turn of the millennium. While she found that compounding did emerge as the most common wordformation device, she did not list any rhyming/alliterating sequences within this group.

Perhaps it is the relative infrequency of rhyming and alliterating compounds in Hungarian that accounts for the sparse discussion of this pattern in studies of Hungarian morphology, which usually treat such instances as one-off analogous formations and relegate them to the poetic realm, as opposed to everyday language use (see, for example, Kiefer and Ladányi 2000: 155). While Kiefer (1999: 264), does refer to rhyming compounds such as icipici ['tiny, teenieweenie'] as "twin words" (ikerszó), he does not analyze them as compound expressions.

Recent studies, however, attribute a more significant role to rhyming and alliterating compounds in everyday language use (see for example Ladányi 2007, Sólyom 2012, Benczes 2014). For instance, Benczes (2014) claims that rhyming and alliterating patterns serve a number of important pragmatic functions in everyday Hungarian, such as signaling informality. In order to prove her point, Benczes cites two examples from Népszótár, a now defunct Hungarian webbased dictionary that could be freely edited by the users (www.nepszotar.hu). Her first example, tréfarépa (tréfa ['joke'] + répa ['carrot']; 'person who tells a lot of boring jokes; a buffoon'), is most probably motivated by the PEOPLE ARE PLANTS metaphor, which is a highly prevalent metaphor in our conceptualization, as attested by the following conventionalized expressions: she's withering away, he's a late bloomer, he's a young sprout (Kövecses 2002: 229). What is peculiar about tréfarépa is that it is rather ironic — somebody who is called a "joke carrot" is by no means actually funny. The clash between the literal meaning ("joke carrot") and the intended meaning ("buffoon") is signaled by the informal form, that is, the rhyming sequence, which indicates that there is a play on the literal meaning; the meaning should not be taken "seriously," word for word. It is highly probable that the motivation for the selection of the two constituents, tréfa and répa, was rhyme. This hypothesis is supported by Benczes' other example from Népszótár, the synonymous poénpadlizsán, literally "punchline eggplant” (poén ["punchline']+ padlizsán ['eggplant']), which is also based on the PEOPLE ARE PLANTS metaphor. Similarly to tréfarépa, phonological criteria must have motivated the selection of the constituents, as poén and padlizsán alliterate.

Informality — and a substantial amount of language play—also underlies pannon puma, a euphemistic expression for Hungary's economic performance, which is traceable via analogy to ázsiai tigris, itself a direct translation of the English expression Asian tiger (referring to the highgrowth economies of Hong Kong, Singapore, South Korea, and Taiwan). The motivation of the head element, tiger, in the original expression goes back to the ECONOMY IS A TIGER metaphor, which conceptualizes the Asian economy as a strong, powerful, and fast-moving animal. The latter characteristic is of special significance: Hong Kong, Singapore, South Korea, and Taiwan 
Benczes, Réka and Erzsébet Tóth-Czifra. "Language Play and Linguistic Hybridity as Current Trends in Hungarian Word-Formation." Hungarian Cultural Studies. e-Journal of the American Hungarian Educators Association, Volume 8 (2015): http://ahea.pitt.edu DOI: 10.5195/ahea.2015.212

experienced exceptionally high growth rates from the 1950s and 1960s onwards. In addition, the expression is also motivated by metonymies. On the one hand, the animal (the tiger) stands for the territory (Southeast Asia); on the other hand, a prototypical animal of the region (the tiger) stands for all the possible animals found in the region.

What is interesting about pannon puma is that the metonymies of the original compound are not valid in Hungarian, as there are no pumas in Hungary. Nevertheless, the compound "borrows" the underlying ECONOMY IS A TIGER metaphor, but does so with a twist-pannon puma is conceptually analogous to Asian tiger as it is based on a similar (but not identical) conceptualization of economies as felines In this sense, pannon puma is a linguistic hybrid: its metaphorical conceptualization is a "borrowing." However, what licenses puma is the alliterating modifying constituent, pannon (which is the adjectival form of Pannónia, the name of the Roman province that occupied the territory of present-day Western Hungary). The irony (or humor) of the meaning of the compound is brought out by the alliterating sequence, which signals informality of meaning, i.e. a non-literal interpretation. The humor of the expression can be attributed to the apparent dissimilarity between the developed economies of the Asian tigers and the laggard economy of Hungary. In this sense, pannon puma is indeed an "extended pun" (Amritavalli and Upendran 2011: 104), as it bridges two languages, and its humor is made fully apparent through the knowledge of the original (English) expression.

\section{Creative Prefixations}

It has often been pointed out in both academic and non-academic discourse that the internet (or more specifically, the social media) is by far the most dominant source and context of the spread of English. That is, due to the fact that internet communication is predominantly in English, it provides an overflow of English language input to its users. The resulting linguistic interference phenomenon, i.e. borrowing, is not restricted to isolated words or expressions, such as tablet and router, or loan translations like honlap and böngészö (calqued on 'webpage' and 'browser,' respectively); linguistic interference also manifests itself in the form of complex, hybrid constructions. From the late 2000s onwards, an array of creative prefixations such as meggugliz ['to google'], ', belájkol [lit. 'to like in (sg. on facebook)'] lecsekkol [lit. 'to check out'], felhájpol or túlhájpol [lit. 'to hype up' or 'to overhype'], elszkippel [lit. 'to skip away'] entered Hungarian. The popularity of this novel word-formation trend is well reflected by the fact that meggugliz and (be)lájkol were chosen (among others) as "words of the year" in 2010 in Hungary.

Why are such coinages so popular among speakers? We believe that the answer to this question rests in the unconventional makeup of belájkol, meggugliz, etc. Although they follow a very productive and well-entrenched schema of Hungarian word-formation of [prefix...- Vz(ik) /$\mathrm{V}(1)$ ], the schema is instantiated by English loanwords, which, however, follow Hungarian orthography (e.g., Google $\rightarrow$ gugli; like $\rightarrow$ lájk; hype $\rightarrow$ hájp; skip $\rightarrow$ szkipp). The process results in hybrid words: the core element is an English verb from which a Hungarian verb is derived by "surrounding" or "embracing" it by the [verbal prefix+denominal affix] pattern, as depicted in Figure 1.

\footnotetext{
2 The verbal prefix meg-indicates the completeness (perfectivity) and resultativeness of the action of googleing.
} 
Benczes, Réka and Erzsébet Tóth-Czifra. "Language Play and Linguistic Hybridity as Current Trends in Hungarian Word-Formation." Hungarian Cultural Studies. e-Journal of the American Hungarian Educators Association, Volume 8 (2015): http://ahea.pitt.edu DOI: 10.5195/ahea.2015.212

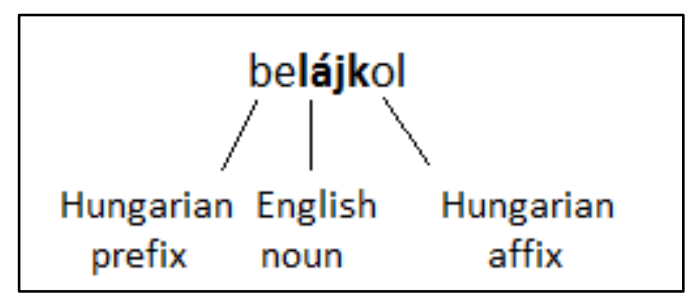

Figure 1. English and Hungarian elements in the hybrid expression belájkol.

The tension between a very familiar, frequently used and inherent feature of Hungarian (that is, the morphological pattern) and the unfamiliar and unexpected English element lends the coinage an attention-seeking and playful character, which makes it a popular word choice among the younger generation. Nevertheless, this clash between the familiar Hungarian pattern and the unfamiliar foreign (English) content is not the only source of creativity of such constructions. The other source can be tied to what Balogh (2000: 265) refers to as the "competing nature" of Hungarian verbal prefixes. In other words, why do speakers select meg- in the expression meggugliz or be in belájkol, etc., as opposed to any other prefix? The most probable reason for the selection of the respective prefixes is (morphological) analogy to highly conventional Hungarian synonyms; each and every hybrid construction has a Hungarian equivalent with an identical prefix. Accordingly, meggugliz ['to google'] is modeled on megkeres ['to search'], belájkol ['to like (sg. on facebook)'] evokes bejelöl [lit. 'to mark in'], lecsekkol ['to check'] evokes leellenöriz [the conventional expression for 'to check'], felhájpol or túlhájpol ['to hype, to overhype'] evokes felkap [the conventional expression for 'to hype'] or túlértékel ['to overvalue'], and finally, elszkippel ['to skip'] evokes ellóg [the conventional expression for 'to skip'], respectively. At this point a further question can be raised. If there are already existing, frequently used expressions with transparent meanings, then why do speakers come up with neologisms referring to more or less the same concept? In other words, what is the difference between megtalál and meggugliz for example? We argue that the answer to this question lies in two interrelated features of these neologisms: 1) their unconventional and attention-seeking character; and 2) their compactness. In order to support this claim, we will provide a blend-based analysis of meggugliz, one of the most prominent members of this cluster of hybrid neologisms.

As stated above, hybrid constructions emerge from the partial integration of two previously unrelated contexts or domains, a process which can be best captured by conceptual blending or conceptual integration (Fauconnier and Turner 1998, 2002, see Sólyom 2014 for the application of conceptual blending to Hungarian verbal prefixes). Conceptual blending is a theory of cognition according to which we routinely (and unconsciously) blend together the elements and relations of different mental spaces or domains to form a blended or "emergent" structure. Conceptual integration is typically presented in a diagrammatic form, where the two interacting mental spaces (called "input spaces") are represented by circles. Additionally, there is an optional third space, the so-called "generic space," that maps onto each of the inputs and provides a common schema for both inputs. Finally, the result of the integration of the input spaces, the emergent construction or "blend," is represented in the fourth space, the blended space (Fauconnier and Turner 2002: 41).

The blend-based analysis of the expression meggugliz is represented in Figure 2. Here the Generic Space providing the overall frame of reference of the conceptual integration is the 
conceptual domain of "searching" or "looking for something" "keresés" in Hungarian). The two input spaces, compatible with this generic space, are the highly productive [meg...-(V)z(ik)] word-formation pattern or schema on the one hand and the domain of "internet search" on the other. The former is at work in the construction of an array of frequently used Hungarian verbs, such as megkérdez ['to ask'], megfelez ['to cut in half'], megvajaz ['to spread butter (on bread)'], etc.

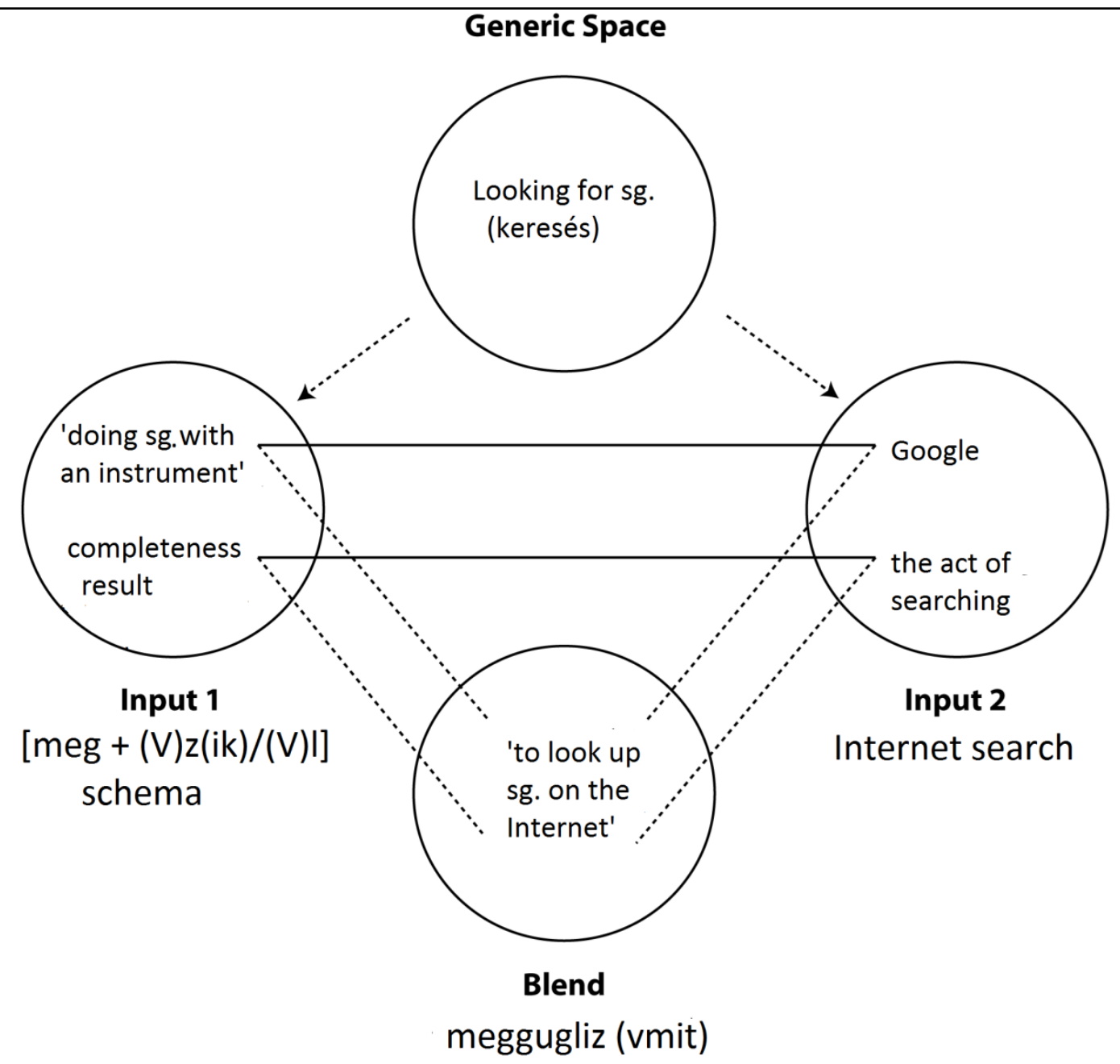

Figure 2. The blend analysis of meggugliz.

There are a number of specific relationships that can be identified between the generic space and the two input spaces. The highly conventional construction schema in Input Space 1 specifies the manner of the action, since the verbal prefix meg- signals the completeness (i.e., the perfectivity or telicity) and resultativeness of a given action (Szili 2001), which in our case is looking for something. At the same time there is a certain degree of specialization in the Generic Space and Input Space 2, since an internet search is a specific form of the general action of 
Benczes, Réka and Erzsébet Tóth-Czifra. "Language Play and Linguistic Hybridity as Current Trends in Hungarian Word-Formation." Hungarian Cultural Studies. e-Journal of the American Hungarian Educators Association, Volume 8 (2015): http://ahea.pitt.edu DOI: 10.5195/ahea.2015.212

searching or looking for something. Furthermore, there is a set of specific correspondences or mappings (indicated by unbroken lines in the diagram) that characterize the relationship between the two input spaces. The schematic meaning of the affix $[-(\mathrm{V}) \mathrm{z}(\mathrm{ik})]$ element of the $[\mathrm{meg} . . .-$ (V)z(ik)] construction schema is "to do sg with sg" (Ladányi 2007: 105). As such, it corresponds to the "Google" element of Input Space 2, since Google is a typical instrument for internet searches; therefore, these two elements of the two inputs correspond to and mutually elaborate one another. Additionally, the two input spaces project an array of conceptual material into the Blend (indicated by dotted lines in the diagram). That is, the Blend contains an emergent structure which inherits some elements from both input spaces. First, the means of searching and the verbal profile of the construct itself (i.e., that it is an action) is projected onto the Blend from Input Space 1. Second, the Generic Space and Input Space 1 jointly evoke the expression megkeres, which provides the (analogy-based) motivation for the selection of the prefix meg- in the resulting verb meggugliz. The most typical instrument for internet searches, the search engine Google, is projected onto the Blend from Input Space 2, thereby instantiating an instrument-foraction metonymy. In sum, the resulting blend (meggugliz) is a lexically and semantically compact expression that is based on a complex network of semantic mappings, and which, due to its unconventional makeup, is capable of evoking two quite distinct contexts at the same time.

As already stated above, the compactness and unconventionality of meggugliz and other similar hybrid forms make them particularly popular in colloquial Hungarian. More and more expressions following the same [prefix+English noun $+-(\mathrm{V}) \mathrm{z}(\mathrm{ik}) /-(\mathrm{V}) \mathrm{l}]$ pattern can be observed, and their semantic field is no longer restricted to the internet (see, e.g., elszkippel ['to skip'] or lecsekkol ['to check']), which indicates the generalization and extension of this word-formation pattern as a general strategy for coining novel, attention-seeking, and highly creative expressions. Through their increased use, the sense of otherness (i.e. the English element) is slowly eroded as the expressions become integrated into the linguistic and conceptual system of Hungarian. The increasing number of such constructions suggests that a new word-formation subschema is emerging within the very well-entrenched and productive schema of [prefix... (V)z(ik)/-(V)l].

Creative neologisms such as pannon puma or meggugliz play an important role in everyday communication and interpersonal relationships. New words are often coined for attention-seeking or foregrounding, and attention-seeking is best achieved via witty, creative wordplay that is often based on puns and the deliberate bending or breaking of rules (Hohenhaus 2007, Lehrer 2003). However, as underlined by Lehrer (2003: 370), the underside of creativity is that such words often need more effort on the side of the reader/hearer to interpret. Why then do we engage in novel and creative word formation? According to Lehrer, the answer lies in the satisfaction that we feel when we are able to figure out the meaning of a novel expression. This feeling reinforces within us a positive attitude toward the "speech event and possibly toward the speaker and the referent of the neologism. If a positive attitude is created, this will reinforce the speaker's intention if the goal is for the hearer to remember the item (and maybe buy the product)" (Lehrer 2003: 370), and, ultimately, to create a rapport between the participants of the speech situation. In their list of social and discourse functions for humor and wit, Long and Graesser (1988: 57) note that witty, creative language is not used to maintain discourse management or social control, but is sometimes "generated for fun as social play," in order to build up "camaraderie," "strengthen social bonds," and "foster group cohesiveness." 
Benczes, Réka and Erzsébet Tóth-Czifra. "Language Play and Linguistic Hybridity as Current Trends in Hungarian Word-Formation." Hungarian Cultural Studies. e-Journal of the American Hungarian Educators Association, Volume 8 (2015): http://ahea.pitt.edu DOI: 10.5195/ahea.2015.212

\section{Conclusions}

The aim of this paper was to demonstrate how linguistic creativity and the influence of English jointly motivate novel Hungarian word-formation strategies. More specifically, the paper focused on two such trends: 1) rhyming and alliterating compounds such as pannon puma (a euphemism for Hungary's economic performance, a play on the analogy of the "Asian tiger"); and 2) creative prefixations such as meggugliz ['to google'] and felhájpol ['to hype']. These patterns exhibit different manifestations of linguistic hybridity. In the case of rhyming and alliterating compounds, the individual morphemes are part and parcel of the Hungarian lexicon, but the word-formation schema itself can be considered as a borrowing-rhyme and alliteration in compounding is less typical in Hungarian, while it is quite characteristic in (American) English neologisms. In the case of meggugliz and felhájpol, however, the reverse happens: here, the schema [prefix... -(V)z(ik)/-(V)l] is an inherent and highly productive feature of Hungarian, but the bases that instantiate the schema are English loanwords.

Despite the apparent diversity of these patterns, they share an array of common features. First, both of these newly emerged word-formation patterns are heavily influenced by language play and analogy: phonological analogy in tréfarépa, conceptual analogy in pannon puma and morphological analogy in creative prefixations, such as meggugliz. Second, such expressions are often coined for attention-seeking purposes. These shared features enable them to serve a range of communicative and pragmatic functions, such as triggering positive attitudes and creating a social bond among language users. Undoubtedly, such expressions are mostly informal and colloquial in nature; it is a question of future research to what degree rhyming and alliterating compounds and creative prefixations will undergo lexicalization and enter standard Hungarian vocabulary. The findings of the present paper, nevertheless, indicate that word-formation strategies based on creativity, language play, and linguistic hybridity are becoming increasingly popular - it is very likely that coinages of the pannon puma, tréfarépa, and meggugliz types are here to stay.

\section{Works Cited}

Algeo, John. 1998. "Vocabulary." In The Cambridge History of the English Language. Volume IV: 1776-1997. Ed., Richard M. Hogg. Cambridge: Cambridge UP: 57-91.

Amritavalli, Richard and Subrahmanian Upendran (in conversation with G. D. Jayalakshmi). 2011. Word Play Across Languages and Cultures. In Creativity in Language and Literature: The state of the Art. Eds., Joan Swann, Rob Pope, and Ronald Carter. Houndmills: Palgrave Macmillan: 103-5.

Balogh, Judit. 2000. “Az igekötő” ['The Verbal Prefix']. In Magyar grammatika ['Hungarian Grammar']. Ed., Borbála Keszler. Budapest: Nemzeti Tankönyvkiadó: 266-70.

Benczes, Réka. 2012. Just a Load of Hibber-gibber? Making Sense of English Rhyming Compounds. Australian Journal of Linguistics 32/3: 299-326.

. 2013. The Role of Alliteration and Rhyme in Novel Metaphorical and Metonymical Compounds. Metaphor and Symbol 28/3: 167-84.

- 2014. Ami rímel az stimmel ['What Rhymes Is Right']. In MANYE XXIII.

Konferenciakötet ['Conference Proceedings of the 23rd Meeting of the Society of Hungarian Applied Linguists']. Eds., Mária Ladányi, Zsuzsa Vladár, and Éva Hrenek Budapest: Tinta Könyvkiadó: 109-14. 
Benczes, Réka and Erzsébet Tóth-Czifra. "Language Play and Linguistic Hybridity as Current Trends in Hungarian Word-Formation." Hungarian Cultural Studies. e-Journal of the American Hungarian Educators Association,

Volume 8 (2015): http://ahea.pitt.edu DOI: 10.5195/ahea.2015.212

Boogaart, Ronny and Theo Janssen. 2007. "Tense and Aspect.” In The Handbook of Cognitive Linguistics. Eds., Dirk Geeraerts and Hubert Cuyckens. New York: Oxford UP: 803-28.

Comrie, Bernard. 1976. Aspect: An Introduction to the Study of Verbal Aspect and Related Problems. Cambridge: Cambridge UP.

Crystal, David. 1996. Language Play and Linguistic Intervention. Child Language Teaching and Therapy 12/3: 328-44. - 1998. Language Play. London: Penguin Books.

Fauconnier, Gilles and Mark Turner. 2002. The Way We Think: Conceptual Blending and the Mind's Hidden Complexities. New York: Basic Books. 1998. Conceptual Integration Networks. Cognitive Science 22/2: 133-87. - 1996. Blending as a Central Process of Grammar. In Conceptual Structure, Discourse, and Language. Ed., Adèle Goldberg. Cambridge: Cambridge UP: 113-30.

Földes, Csaba. 2014. "A posztmodern és a különbözőség: kultúra, interkulturalitás és hibriditás mint kulcsszavak az alkalmazott nyelvészetben ['Postmodernism and Différence: Culture, Interculturality and Hybridity As Key Terms in Applied Linguistics']." In MANYE XXIII. Konferenciakötet ['Conference Proceedings of the 23rd Meeting of the Society of Hungarian Applied Linguists']. Eds., Mária Ladányi, Zsuzsa Vladár, and Éva Hrenek. Budapest: Tinta Könyvkiadó, 23-41.

Friederici, Angela D., Manuela Friedrich and Anne Christophe. 2007. Brain Responses in 4month-old Infants Are Already Language Specific. Current Biology 17: 1208-11.

Geller, Linda G. 1985. Wordplay and Language Learning for Children. Urbana: National Council of Teachers of English.

Hladký, Josef. 1998. "Notes on Reduplicative Words in English.” Brno Studies in English 24. Brno: Brno UP, 33-78.

Hohenhaus, Peter. 2007. "How to Do (Even More) Things with Nonce Words." In Lexical Creativity, Texts and Contexts. Ed., Judith Munat. Amsterdam \& Philadelphia: John Benjamins, 15-38.

Jakobson, Roman. 1960. "Linguistics and Poetics." In Style in Language. Ed., Thomas A. Sebeok. Cambridge, MA: MIT Press, 350-77.

J. Soltész, Katalin. 1959. Az ösi magyar igekötők ['The Ancient Hungarian Verbal Prefixes']. Budapest: Akadémiai Kiadó.

Kiefer, Ferenc. 1994. “Aspect and Syntactic Structure.” In The Syntactic Structure of Hungarian. Eds., Ferenc Kiefer and Katalin É. Kiss. New York: Academic Press, 415-64.

. 2010. "Areal-typological Aspects of Word-formation: The Case of Aktionsart-formation in German, Hungarian, Slavic, Baltic, Romani and Yiddish." In Variation and Change in Morphology: Selected Papers from the 13th International Morphology Meeting, Vienna, February 2008. Eds., Franz Rainer, Wolfgang U. Dressler, Dieter Kastovsky and Hans Christian Luschützky. Amsterdam: John Benjamins: 129-48.

Kiefer, Ferenc and Mária Ladányi. 2000. "A szóképzés" ['Word-formation']. In Strukturális magyar nyelvtan 3: Morfológia ['Structural Hungarian Grammar 3: Morphology']. Ed., Ferenc Kiefer. Budapest: Akadémiai Kiadó: 137-64.

—. 2000. “Az igekötők" ['Verbal Prefixes']. In Strukturális magyar nyelvtan 3: Morfológia ['Structural Hungarian Grammar 3: Morphology']. Ed., Ferenc Kiefer. Budapest:

Akadémiai Kiadó: 453-518.

Kövecses, Zoltán. 2002. Metaphor: A Practical Introduction. Oxford: Oxford UP. 
Benczes, Réka and Erzsébet Tóth-Czifra. "Language Play and Linguistic Hybridity as Current Trends in Hungarian Word-Formation." Hungarian Cultural Studies. e-Journal of the American Hungarian Educators Association,

Volume 8 (2015): http://ahea.pitt.edu DOI: 10.5195/ahea.2015.212

Ladányi, Mária. 2007. Produktivitás és analógia a szóképzésben: elvek és esetek ['Productivity and Analogy in Word Formation: Principles and Case Studies']. Budapest: Tinta Könyvkiadó.

Lehrer, Adrienne. 2003. Understanding Trendy Neologisms. Rivista di Linguistica 15/2: 369-82.

Long, Debra L. and Arthur C. Graesser. 1988. "Wit and Humor in Discourse Processing." Discourse Processes 11: 35-60.

McGlone, Matthew S. and Jessica Tofighbakhsh. 2000. "Birds of a Feather Flock Conjointly (?): Rhyme as Reason in Aphorisms." Psychological Science 11/5: 424-8.

Mehler, Jacques, Paul Jusczyk, Ghislaine Lambertz, Nilofar Halsted, Josaine Bertoncini, and Claudine Amiel-Tison. 1988. "A Precursor of Language Acquisition in Young Infants." Cognition 29/2: 143-78.

Oxford English Dictionary 1989. 2nd ed. Online version. Oxford: Oxford UP.

Pennycook, Alastair. 2003. "Global Englishes, Rip Slyme and Performativity." Journal of Sociolinguistic Research 7/4: 513-33.

Rastall, Paul. 2004. "Playful English: Kinds of Reduplication." English Today 80/20: 38-41.

Sólyom, Réka. 2009. "Neologizmusok a mai magyar szókészletben" ['Neologisms in the Contemporary Hungarian Lexicon']. In FÉLÚTON 3. ['Conference Proceedings of the $3^{\text {rd }}$ Félúton Conference']. Eds., Ágnes Kuna and Ágnes Veszelszki: 260-73. - 2012. "Fórumszövegek vizsgálata: neologizmusok elemzése a szemantikai felépítés és a stílus szociokulturális rétegzettségének vonatkozásában" ['Forum Texts: The Analysis of Neologisms In Relation to Their Semantic Makeup and the Sociocultural Aspects of Style']. In A stílus szociokulturális tényezöi. Kognitív stilisztikai tanulmányok ['Sociolinguistic Aspects of Style: Studies in Cognitive Stylistics']. Eds., Szilárd Tátrai and Gábor Tolcsvai Nagy. Budapest: ELTE: 263-99.

- 2014. "Semantic Features of Hungarian Neologisms With the Prefix Be: Analysis of Some Frequently Used Verbs (e.g., bevállal)." Hungarian Cultural Studies: E-Journal of the American Hungarian Educators Association 7: 358-73.

Szili, Katalin. 2001. "A perfektivitás mibenlétéről a magyar nyelvben a meg- igekötő funkciói kapcsán" ['On Perfectivity in Hungarian. A Case Study of the Hungarian Prefix meg]. Magyar Nyelv 97: 356-69.

Tannen, Deborah. 2007. Talking Voices: Repetition, Dialogue and Imagery in Conversational Discourse. Cambridge: Cambridge UP.

Thomason, Sarah. 2001. Language Contact: An Introduction. Georgetown: Georgetown UP.

Veszelszki, Ágnes. 2011. "Neologizmusok a digilektusban, különös tekintettel a szóképzésekre" ['Neologisms in Digilects, with Special Reference to Word-formation']. In Tegnapi filológiánk mai szemmel ['Yesterday's Philology from Today's Point of View']. Ed., Vilmos Bárdosi. Budapest: Tinta Könyvkiadó, 157-65.

Veszelszki, Ágnes et al. 2012. Netszótár. @-tól a zukbergnetig ['Internet Dictionary: From @ to the zukbergnet']. Budapest: ELTE Eötvös Kiadó.

Vouloumanos, Athena and Janet F. Werker. 2007. "Listening to Language at Birth: Evidence for a Bias for Speech in Neonates." Developmental Science 10/2: 159-71.

Weir, Ruth H. 1962. Language in the Crib. The Hague: Mouton. 